\title{
Diversity of Plants yielding Unorganized Drugs From Nandgaon and Chandwad tehsils District Nashik (Maharashtra)
}

\author{
Kokate Darshan Madhukar *, Gaikwad Krishna Nathu \\ Department of Botany K.S.K.W. College, Cidco Nashik, \& P.G Department of Botany K.T.H.M College Nashik
}

(M.S.) India. [Affiliated to Savitribai Phule Pune University, Pune]

Address for Correspondence: Kokate Darshan Madhukar, darshankokate43@gmail.com

\begin{tabular}{l} 
Received: \\
01.02.2019 \\
Accepted: \\
15.08.2019 \\
Keywords \\
Diversity, \\
Unorganized \\
drugs, critically \\
endangered, \\
Nasik District. \\
\hline
\end{tabular}

\section{INTRODUCTION}

Out of the various products obtained from forest, Gum and resins have been an important commodity of commerce, providing livelihood to people living in and around forest. Besides other uses, these products (Gum and resins) have been used in medicines, in traditional medicinal systems like Ayurveda and Unani .They are also being used in Allopathic formulations. Owing to their economical and medicinal values the plants yielding these products are required to be conserved, preferably in their natural habitats .Floristic studies are stepping stones towards conservation of plants Nandgaon and Chanwad tehsils comprise of hill areas and wilderness with dry deciduous vegetation. Plants were photographed and identified with the help of floras. During the floristic studies of the area following important plants yielding Un organized drugs (Gums and resins) were recorded.

Enumeration -along with medicinal uses.

\begin{abstract}
Anogeissus latifolia (DC.) Wallich ex Guill. \& Perr. Fl. Seneg.Tent.1:280.1832:C.b.Cl in Hook.f.Fl.Brit.India 2 : 450. 1878; Cooke, Fl. Pres. Bombay 1:512.1958 ; Scott in Kew Bull.33:560.1979.Conocarpus latifolia Roxb ex DC. Prodr,3 :17 1828 .

Family Combretaceae
\end{abstract}

\section{Gum Ghatti}

Trees up to 18 meters high. Bark smooth whitish grey. Leaves ovate elliptical with obtuse apex. Flowers sessile present on dense globose heads on stalks in axils of leaves. Flowers small pentamerous with persistent calyx. Fruits a two winged pseudo calyx.

Flowering and fruiting -September - February

Mahadeo dongar, Indrai

Frequent

Medicinal uses - Traditionally used after childbirth, as a tonic and galactogogue, Dysentery 
Indo Global Journal of Pharmaceutical Sciences, 2019; 9(2): 84-86

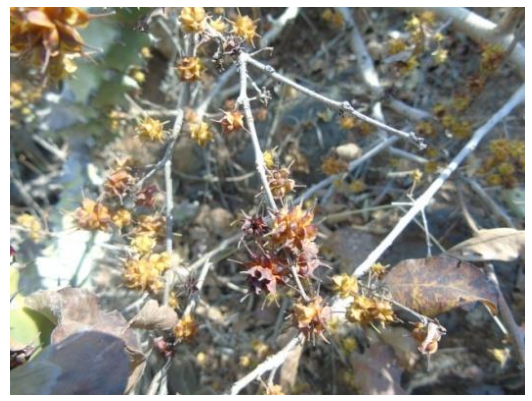

Commiphora wightii (Arn.) Bhandari in Bull .Bot Surv. India 6.327. \& Fl. Indian Des.96, f.34.1978. Balsamodendron wightii Arn.in Ann.Nat.Hist.Soc.3; 86.1839

Family -Burseraceae

Myrrh, Guggulu

Spiny Shrub, up to 4 meters high with thin white papery bark. Leaves rhomboid - ovate in shape with serrate or toothed margins in upper parts, 1- 3 foliate with sub sessile leaflets

Boswellia serrata Roxb.ex.Colebr.in Asiat.Res.9; 379, t.5. 1807; Bennet in Hook.f.Fl.Brit.India 1:528. 1875; Cooke .Fl.Pres.Bombay 1:210.1958

Family -Burseraceae

Sallai Guggul

Trees Endemic to India, up to 6 meters tall, occurring on dry hill slopes. Bark ash colored papery, young shoots pubescent, Leaves pinnately compound, alternately arranged, ovate lanceolate, with toothed margins ,Inflorescence of racemes ,flowers small creamy, stamens 10 ,stigma trifid with short style .Fruits trigonous drupes.

Flowering and fruiting - February -May

Jambutke, Hatti, Mahadevdongar

Occasional

Medicinal uses - Antirheumatic, Used in treatment of polyarthritis, and remissions in inflammatory bowel diseases, Ulcerative Colitis and Crohn's disease. Stomach complaints, Ulcers, Fever ,Jaundice, Piles ,Skin diseases.

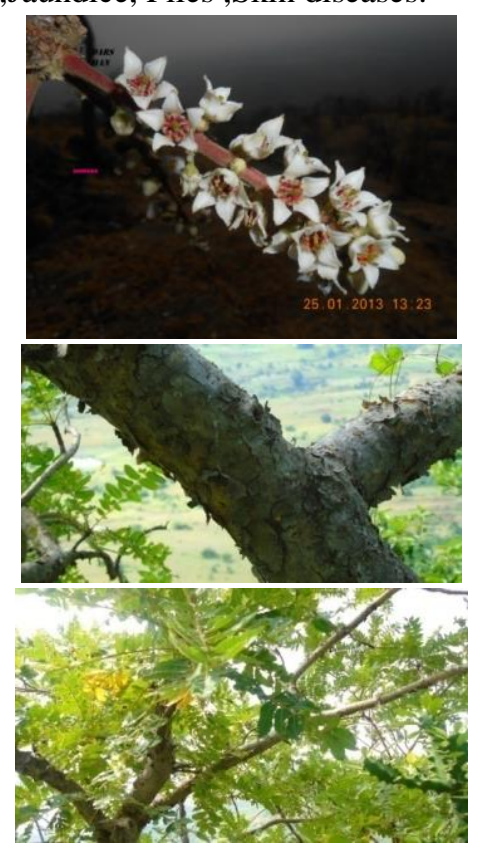
.Flowers brownish red in group of 2 or 3. It is Gynodioecious, some plants have Male and bisexual flowers, while others have female flowers. Drupes about $1 \mathrm{~cm}$, red at maturity.

Flowering and fruiting -March to May

Occurrence Shelkewadi Very Rare Critically endangered

Medicinal uses - Arthritis, Rheumatism, Hemorrhoids, Urinary disorder, obesity, skin disease and high cholesterol,

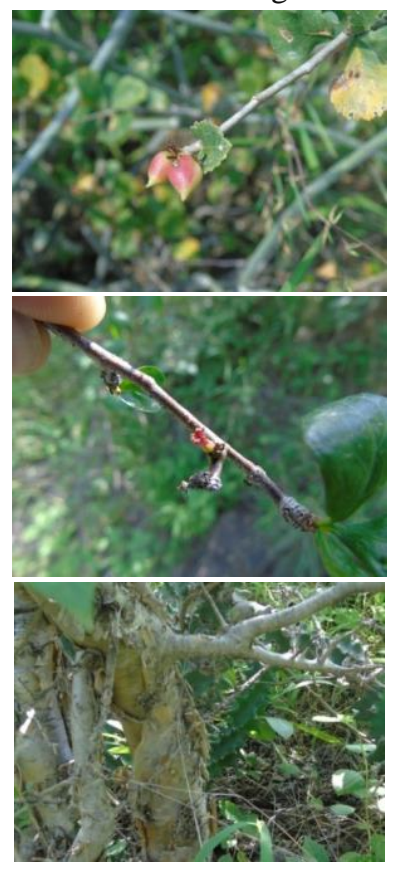

Sterculia urens Roxb.P1 .Cor.1:25, t.24.1795; Mast in Hook. f. Fl Brit. India 1:355. 1874; Cooke, Fl. Pres. Bombay 1:131.1958. Mallick in Sharma et al .Fl. India 3:470.1993

Fam-Sterculiaceae

Gum Karaya, Gum Tragacanth

Deciduous trees about 15 meters high, young parts pubescent, bark greyish white, smooth shining, peeling off in papery flakes. Leaves shallowly palmately five lobed, crowded on tips of branches on long petioles. Inflorescence branched, glandular pubescent, flowers greenish yellow, follicles 4-6 ovoid -oblong covered with stinging bristles.

Flowering, fruiting December-April 
Indo Global Journal of Pharmaceutical Sciences, 2019; 9(2): 84-86

Chandreswar ,Pardhadi ,Mahadeo dongar

Ocassional

Medicinal uses - Dental adhesive, Constipation, Throat infections, Blisters, Joint pain

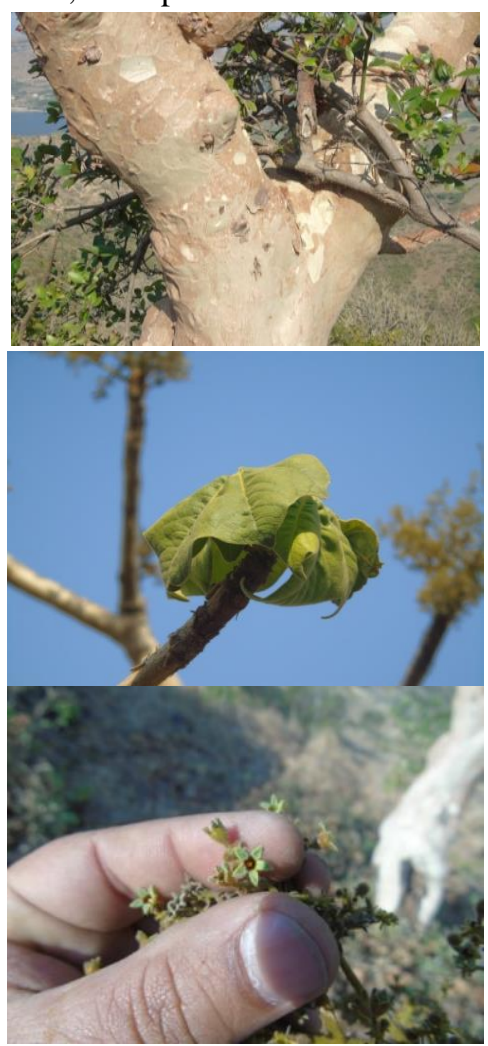

\section{REFERENCES}

1) Chandra Prakash Kala - Important Gum Yielding species -Anogeissus latifolia (Roxb) Bedd, Boswellia serrata Roxb and Sterculia urens Roxb: Ethno botany Population Density and Management -Applied Ecology and Environmental Sciences ,2016 Vol.4 No.3,61-65

2) Qureshi Ikram and Chachar Omprakash - Medicinal use of Endangered plant Commiphora wightii, Variorum Multidisciplinary e-Research Journal Vol,04 Issue I August 2013

3) N.P. Singh and S. Karthikeyan -Flora of Maharashtra State Vol I ,2000, Botanical survey of India

4) P. Lakshminarasimhan and Sharma .B.D Flora of Nasik District 1991,

Botanical survey of India

Indo Global Journal of Pharmaceutical Sciences( ISSN 2249 1023; CODEN- IGJPAI; NLM ID: 101610675) indexed and abstracted in CrossRef (DOI Enabling), UGC CARE Journal List, EMBASE(Elsevier), National Library of Medicine (NLM) Catalog, ResearchGate, Publons, CAS (ACS), Index Copernicus, Google Scholar and many more. For further details, visit http://iglobaljournal.com

This is a special issue as an outcome of 'International Conference on Recent Advances in Traditional Medicine, Medicinal Plants and Phytochemistry' jointly organized by Ahmednagar College, India and AIMST University, Malaysia. Relaxation offered in journal format. 